\title{
Disaster medical assistance in super typhoon Haiyan: Collaboration with the local medical team that resulted in great synergy
}

\author{
Hoon Kim, M.D., ${ }^{1}$ Moo Eob Ahn, M.D., ${ }^{2}$ Kang Hyun Lee, M.D., ${ }^{3}$ \\ Yeong Cheol Kim, M.D., ${ }^{4}$ Eun Seok Hong, M.D. ${ }^{5}$
}

\begin{abstract}
1Department of Emergency Medicine, Inje University Ilsan Paik Hospital, Goyang, Korea;
${ }^{2}$ Department of Emergency Medicine, College of Medicine, Hallym University, Chuncheon, Korea;

${ }^{3}$ Department of Emergency Medicine, Wonju College of Medicine, Yonse University, Wonju, Korea;

${ }^{4}$ Department of Trauma Surgery, National Medical Center, Seoul, Korea;

${ }^{5}$ Department of Emergency Medicine, Ulsan University, Ulsan, Korea
\end{abstract}

\begin{abstract}
BACKGROUND: On 8 November 2013, Typhoon Haiyan made landfalls over the center of the Philippines and devastated the region. Soon aftermath of the disaster, many foreign medical teams (FMTs) headed toward the site, and the Korean team was one of them.

METHODS: This study described the experiences of the team during the initial phase of response, focusing on collaborative efforts with the local medical team.

RESULTS: The Korean team was capable of providing primary care, and the Filipino team provided incomplete secondary care which was insufficient for covering the patient load. Not only did the Korean team provide electricity for hospital operation and various materials, but also supplemented medical personnel, who covered the emergency and outpatient departments. Collaborative efforts filled in each other's gap, and resulted in great synergy.
\end{abstract}

CONCLUSION: Disaster medical relief mission of FMTs should be cooperated with a coordination mechanism. Collaboration with the local resources can be a great opportunity for both parties, and should not be overlooked in any disaster situations.

Key words: Collaboration; disaster; typhoon.

\section{INTRODUCTION}

Category 5 tropical cyclone Yolanda, known as Super Typhoon Haiyan, devastated the Philippines on November 8, 20I3. As of January 29, 20 I4, the death toll had reached $620 \mathrm{I}$ with 1785 missing according to the Philippines National Disaster Risk Reduction and Management Council (NDRRMC). The report of the agency revealed that 28.626 were injured. The typhoon affected fifty-seven cities and more than three

Address for correspondence: Moo Eob Ahn, M.D.

77, Sakju-ro, Chuncheon-si, Gangwon-do 200-704, Republic of Korea 200704 Chuncheon, South Korea

Tel: +82 - 10-9719-7|I 9 E-mail: mooeob@gmail.com

Qucik Response Code Ulus Travma Acil Cerrahi Derg

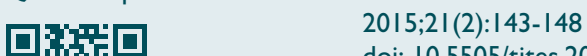

doi: $10.5505 /$ tjtes.2015.54770

Copyright 2015

TJTES million households. Nearly one million families lost their houses while four million people were displaced. ${ }^{[1]}$

Most hospitals and health facilities in the typhoon-hit areas were seriously damaged, and in Tacloban, only one public hospital remained functional following Haiyan. ${ }^{[2]}$

Soon after the tragedy, international aid mechanism was operational, but suffered many difficulties due to logistical problems. The geography of the Philippines produced several similarly affected regions that could not be reached easily. Not every island was covered by aid agencies in a timely fashion due to tackled logistics. World Health Organization (WHO) set up a coordination center for medical aid agencies in Tacloban and Cebu. Korean Disaster Relief Team (KDRT) was one of the foreign medical teams (FMT) that provided medical service in Tacloban. KDRT was deployed on November 15, and started to provide medical service as of November 16 in St. Paul's hospital, Tacloban City. St. Paul's hospital was also severely damaged and partially operated by the Filipino medical team 
deployed from Davao. They treated about two hundred outpatients per day, provided minor surgical services while running thirty patient beds at the time of KDRT's arrival. Four terms of KDRT provided seamless medical services for six weeks thereafter, in cooperation with the Filipino healthcare workers.

This article highlighted initial cooperation efforts from both sides and its effect in hospital function which was greatly enhanced with cooperation.

\section{MATERIALS AND METHODS}

The capacity of KDRT and the Philippines medical team was classified using WHO guidelines and described accordingly. ${ }^{[3]}$ Each team's role in the hospital was described and hospital functions were measured using Inter-Agency Standing Committee (IASC) health service availability checklist form, and the status of before and after collaboration was compared. ${ }^{[4]}$ Operational information including daily reports from both sides were collected to access patient statistics.

\section{RESULTS}

\section{Composition and Capacity of Both Teams}

KDRT consisted of five medical doctors (two emergency physicians, one general surgeon, one orthopedic surgeon, one pediatrician, and one internal medicine specialist), seven nurses, one pharmacist, one radiology technician, three emergency medical technicians, and three medical administrators. KDRT was type I FMT which could provide outpatient emergency care according to the WHO classification. KDRT lacked the capacity to provide maternal-child health care service and inpatient care, which was categorized as primary service in IASC checklist. KDRT brought various equipment for hospital operations which far exceeded type I FMT's capacity. Eight gasoline generators, two blood analyzers, X-ray machine, ultrasonography, and six patient monitors were included. Essential medicines and consumables covering more than 10.000 patients were also included. The Filipino medical team was composed of twenty-one doctors, sixteen nurses, and twenty-eight logisticians. The Filipino team provided inconsistent primary and secondary health care services, but soon was overwhelmed by large patient load. Shortage of electricity and equipment like ultrasonography for prenatal care hampered their activities again. After collaboration, stable provision of most primary and secondary health care services was enabled $24 \mathrm{~h}$ per day. Some tertiary health care services like advanced trauma care were also ensured. Total capacity was upgraded to type 2 FMT, which could provide stable inpatient acute care, general and obstetric surgery for trauma and other conditions (Table I, Fig. I).

\section{Performance of Both Teams}

\section{and the Collaboration Team}

The Filipino team started to work on November 14, which
Table I. Human recourses of KDRT and Filipino team

\begin{tabular}{|c|c|c|c|c|}
\hline Occupation & Specialty & KDRT & Philippines & Total \\
\hline \multicolumn{5}{|l|}{ Doctor } \\
\hline & Emergency medicine & 1 & 1 & 2 \\
\hline & General surgery & 1 & 8 & 9 \\
\hline & Surgical oncology & & 1 & 1 \\
\hline & Orthopedics & 1 & 5 & 6 \\
\hline & Anesthesiology & 1 & 3 & 4 \\
\hline & Internal medicine & 1 & I & 2 \\
\hline & Pediatrics & & 1 & 1 \\
\hline & OB-Gynecologist & & 1 & I \\
\hline & General physician & & 1 & 1 \\
\hline & Sub total & 5 & 21 & 26 \\
\hline Supporting & Nurses & 7 & 12 & 19 \\
\hline Healthcare & Nursing aide & & 3 & 3 \\
\hline \multicolumn{5}{|l|}{ Workers } \\
\hline & EMT & 3 & & 3 \\
\hline & Pharmacist & 1 & & 1 \\
\hline & Radiologic technician & 1 & 1 & 2 \\
\hline & Sub total & 12 & 16 & 28 \\
\hline \multicolumn{5}{|c|}{ Supporting staff } \\
\hline & Administrator & 2 & 2 & 4 \\
\hline & Engineer & 1 & 2 & 3 \\
\hline & Logistician & & 25 & 25 \\
\hline & Sub total & 3 & 28 & 31 \\
\hline & Total & 20 & 65 & 85 \\
\hline
\end{tabular}

was the post-event $6^{\text {th }}$ day. They provided primary care and limited inpatient care for the victims and handled about two hundred outpatients and ten inpatients per day. KDRT started to work on November 16, and collaboration became stable the next day. KDRT was mainly in charge of the outpatient and emergency departments, and the Filipino team started to focus on inpatient care and surgical procedures. Daily number of outpatients increased more than twofold after one week of collaboration, and the number of inpatients was also doubled (Fig. 2, Table 2). Necessary surgeries were performed without compromising outpatient department capacity (Table 3). $24 \mathrm{~h}$ operations, including the emergency department, was enabled due to enough electricity provided by the Korean gasoline generators.

\section{DISCUSSION}

Sudden onset disaster (SOD) in developing countries usually generate large number of sick and injured that overwhelms the local capacity to respond, mandating international assistance. [5] The Philippines suffer damages from typhoons annually, and established National Disaster Risk Reduction\&Management 


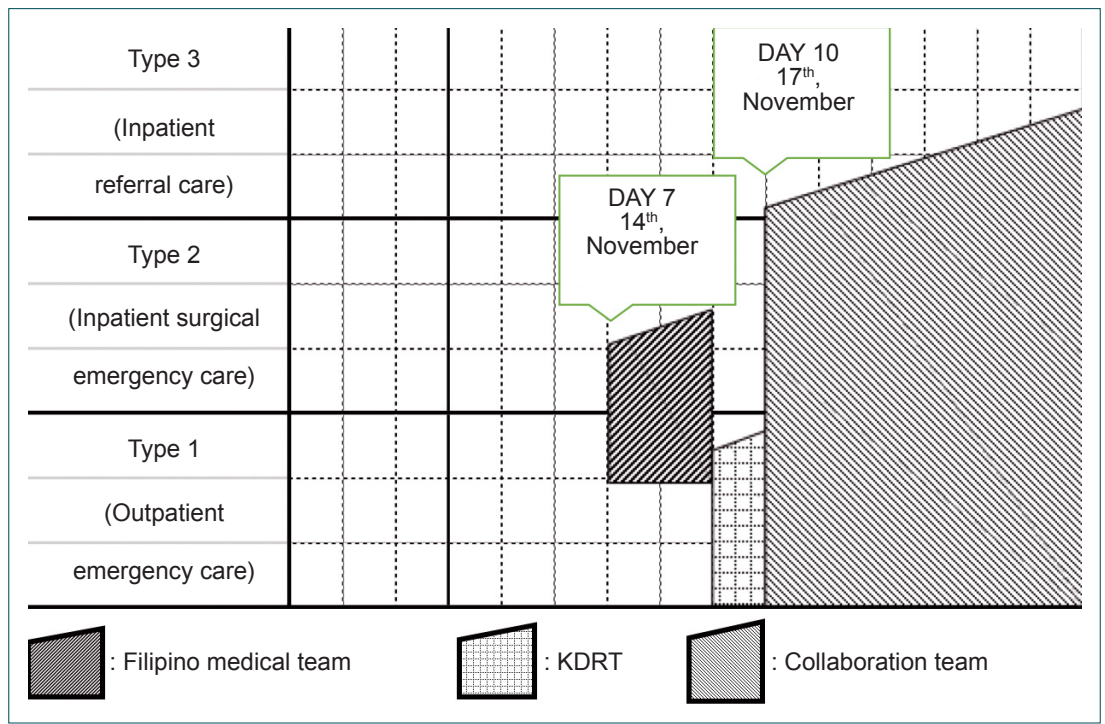

Figure 1. Capacity of KDRT and Filipino team, and collaboration team.

Council (NDRRMC) in 2009, which is a working group of various government, non-government, civil and private sector organizations of the Government of the Philippines to tackle the detrimental effects of natural disasters. Although relatively well prepared to disaster among developing countries, the intensity of Super Typhoon Haiyan was beyond the responding capacity of the Philippines. Most hospitals and health care facilities in the affected regions were not working properly due to structural damage and loss of human resources. Situation was worse in the Eastern Samar area, compared to Tacloban in which many FMTs were in operation. ${ }^{[2]}$

Affected regions were scattered in several islands and trans- port network was hampered during the initial period aftermath of the disaster. After the initial assessment, Korean government decided to deploy consecutive small medical teams rather than bulky field hospital unit. KDRT was the one of the FMTs in Tacloban. As of November I5, KDRT started to participate in health cluster meeting held daily in Tacloban. KDRT was assigned to St. Paul's hospital to help the Filipino medical team which took over the hospital with markedly reduced function in terms of shortage of medicines, consumables, equipment, and especially electricity. At the time of arrival, the Filipino team strived to accommodate flow of victims, and especially the outpatient and emergency departments needed more resources for proper operation. KDRT took

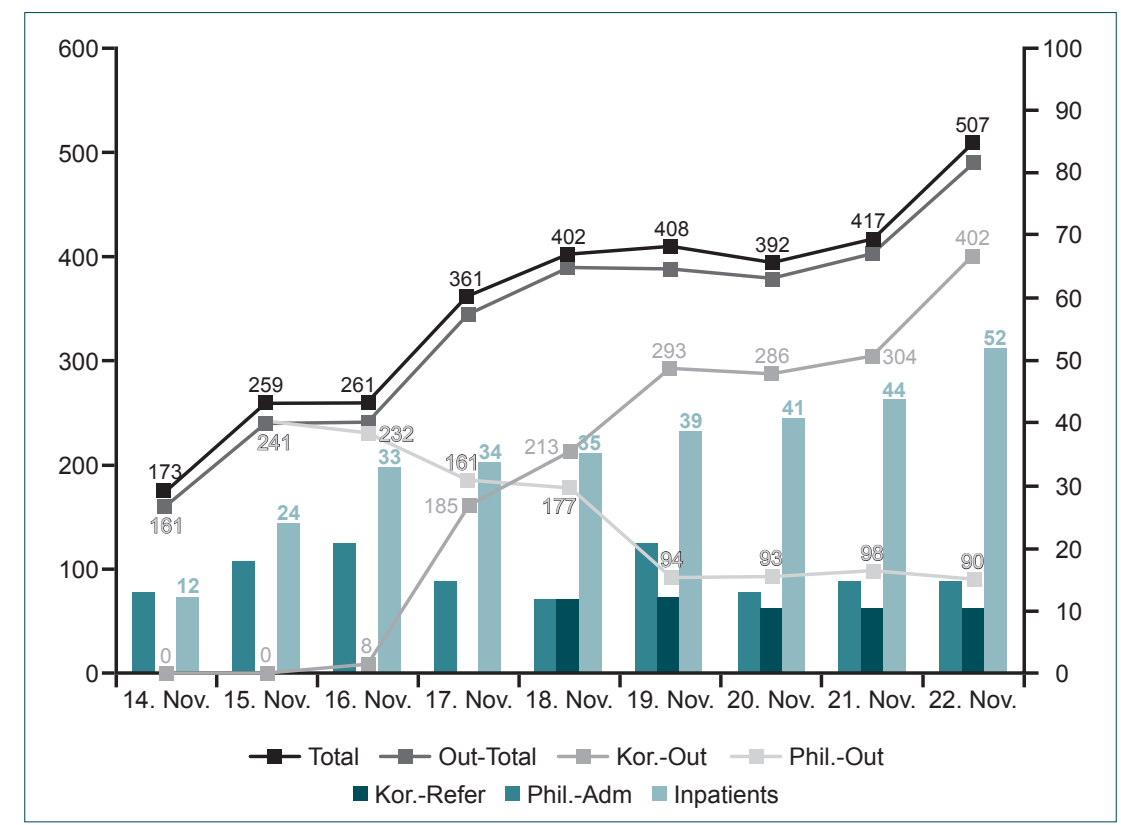

Figure 2. Patient load during KDRT-Philippine cooperation. Phil.-Adm: Philippine admission; Kor.-Refer: KDRT referral; Phil.-Out: Philippine outpatient; Kor.-Out: KDRT outpatient; Out-Total: Total outpatient. 


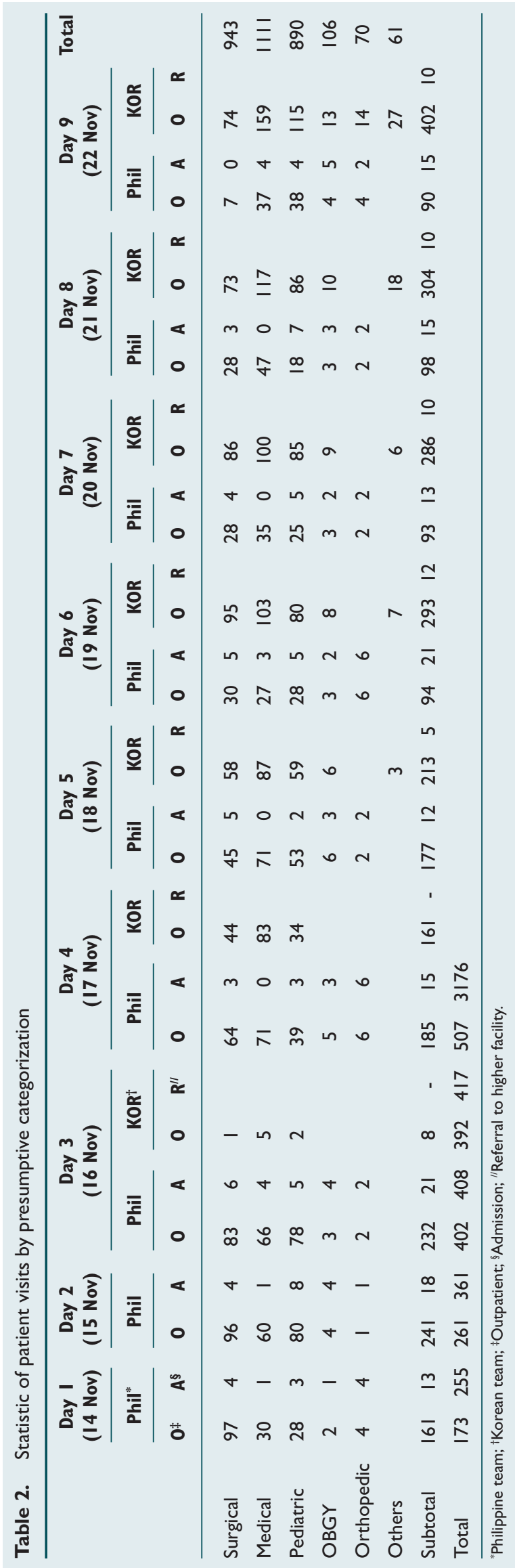

over the whole outpatient department, aided the emergency department, and eight gasoline generators provided enough electricity for the entire hospital so that it could operate 24 hours continuously. The Filipino team was able to focus on inpatient division, and the opening of one more operation theater allowed for surgical procedures. As a result, hospital functions were nearly normalized to pre-disaster status that served virtually all patients visited.

Global humanitarian societies have been responding more vigorously in recent disasters. The Southern Asia tsunami in 2004 and the Haiti earthquake in 2010 are good examples. Nowadays, aid is coming from all over the world as soon as the disaster hits. International organizations with experience in SOD have responded rapidly, and provided essential emergency medical care in coordinated fashion. ${ }^{[6]}$ Well-intentioned, but ill prepared medical teams have also responded and caused detrimental consequences to the victims. ${ }^{[7]}$ Poor cooperation with the local authorities and inadequate medical services, not acceptable in the local context, have been the reasons. ${ }^{\left[{ }^{[8]}\right.}$ Disaster tourists headed to the site without any proper set of knowledge and attitude have been criticized recently. ${ }^{[9]}$ Many unprepared foreign medical teams have operated freely and unmonitored. Lack of coordination has led to duplication of aid in certain regions and gaps in others. Call for accountability and well-organized coordination efforts was announced, and global efforts to tackle the problem were started in the mid 2000's. ${ }^{[10]}$ Cluster approach is one of them and has been endorsed since 2005. WHO is supposed to lead the health cluster and coordinate FMTs on site.

The Korean government has been running a certification course for medical disaster relief team workers since 2009. More than one thousand health care workers have received their accreditation after completing the 3-day training course, and have been eligible for becoming a KDRT member. Among them, around a hundred have also proceeded to a 5-day advanced course, where they have been prepared to work in an austere environment with limited resources. KDRT also possesses deployable 30-bed field hospital with surgical capacity. Geography of the affected area, in this case, posed unique logistical problems, and the Korean government decided to deploy consecutive small group of medical teams rather than well-prepared field hospital.

The capacity of KDRT was limited to be able to provide only outpatient emergency services, and we were arranged by WHO to cooperate with the local medical team in the local hospital. The Filipino medical team, which took over St. Paul's hospital two days prior to KDRT's arrival, suffered from shortage of pharmaceutics and human resources. The hospital function was restricted again, only to provide partial coverage due to shortage of electricity. KDRT replenished the shortages and assumed full charge of the outpatient and emergency departments. Soon, the hospital function was normalized, and the Filipino medical team could concentrate 
Table 3. Type of surgical procedures performed in St. Paul Hospital

\begin{tabular}{|c|c|c|c|c|c|c|c|c|c|c|}
\hline & $\begin{array}{c}\text { Day I } \\
\text { (14 Nov) }\end{array}$ & $\begin{array}{c}\text { Day } 2 \\
\text { (I5 Nov) }\end{array}$ & $\begin{array}{c}\text { Day } 3 \\
\text { (16 Nov) }\end{array}$ & $\begin{array}{c}\text { Day } 4 \\
\text { (17 Nov) }\end{array}$ & $\begin{array}{c}\text { Day } 5 \\
\text { (18 Nov) }\end{array}$ & $\begin{array}{c}\text { Day } 6 \\
\text { (19 Nov) }\end{array}$ & $\begin{array}{c}\text { Day } 7 \\
(20 \text { Nov) }\end{array}$ & $\begin{array}{c}\text { Day } 8 \\
\text { (2I Nov) }\end{array}$ & $\begin{array}{c}\text { Day } 9 \\
(22 \text { Nov) }\end{array}$ & Total \\
\hline Suture & 8 & 5 & 12 & 7 & 6 & 6 & 8 & 6 & 5 & 63 \\
\hline Debridement & 3 & 2 & 3 & 6 & 5 & 4 & 2 & 2 & 4 & 31 \\
\hline Amputation & 3 & I & 0 & 0 & I & 0 & 0 & 0 & 0 & 5 \\
\hline Cesarean section & 2 & 3 & 3 & I & 2 & 0 & 2 & 0 & I & 14 \\
\hline Laparotomy & 0 & 2 & 0 & 0 & 3 & 2 & 0 & 0 & I & 8 \\
\hline Ungiectomy & 0 & 0 & 0 & I & 0 & 0 & 0 & 0 & 0 & I \\
\hline Closed reduction & 0 & 0 & 0 & 0 & I & 0 & I & 0 & 0 & 2 \\
\hline External fixation & 0 & 0 & 0 & 2 & 1 & 2 & 1 & 1 & 0 & 7 \\
\hline \multicolumn{11}{|l|}{ Open reduction } \\
\hline \&Internal fixation & 0 & 0 & 0 & 0 & 3 & 2 & 2 & 0 & 0 & 7 \\
\hline Disarticulation & I & 0 & 0 & 0 & 0 & 0 & 1 & 0 & 0 & 2 \\
\hline Tracheostomy & 0 & 0 & 0 & 0 & 0 & I & 0 & 0 & 0 & 1 \\
\hline Herniotomy & 0 & 0 & 0 & 0 & 0 & I & 0 & 0 & 0 & I \\
\hline Total & 17 & 13 & 18 & 17 & 22 & 18 & 17 & 9 & II & 142 \\
\hline
\end{tabular}

on more sophisticated services such as inpatient care and surgeries. Collaboration of the two teams with limited capacity supplemented each other, and the result was greater than the sum of their capacity.

The limitation of our study was that it only reflected a short period of whole relief work. This situation could be further changed as collaboration continued. However, we tried to focus on the initial disaster response phase when the chaotic situation often overwhelmed, and optimal usage of scarce resource was important.

Efficacy of independent short term medical missions in disasters has been argued elsewhere. ${ }^{[1-13]}$

In Haiti, many limbs were amputated by the FMTs without any future plan for prosthetics and rehabilitation. After the initial massive relief mission, FMTs left and disabled survivors who were forced to produce another huge need for aftercare. ${ }^{[14]}$ Many aid agencies still urge to manage their "own" medical supplies and their "own" patients, without engaging in the coordination mechanism. It can lead to wastes, duplication of services, and inefficiency. ${ }^{[15]}$

FMTs that participate in disaster relief mission should clarify their capacity and limit, and should eagerly engage in formal coordinating mechanisms. Though collaborative operation with the local resources may not look better than separate one, harmonious efforts will produce more benefit to the victims.

\section{Conclusion}

Disaster medical relief mission of FMTs should be cooperated with a coordination mechanism. Collaboration with the local resources can be a great opportunity for both parties, and should not be overlooked in any disaster situations.

\section{Acknowledgement}

The study was not sponsored.

\section{Ethics Aapproval}

The study was approved by the Institutional Review committee of College of Medicine, Hallym University.

Conflict of interest: None declared.

\section{REFERENCES}

1. "SitRep No. 104 Effects of Typhoon "Yolanda" (Haiyan)". National Disaster Risk Reduction and Management Council 2014.

2. Chiu YT. Typhoon Haiyan: Philippines faces long road to recovery. Lancet 2013;382:1691-2. CrossRef

3. World Health Organization. Classification and minimum standards for foreign medical teams in sudden onset disasters. Geneva: WHO; 2013.

4. Inter-Agency Standing Committee. Initial rapid assessment(IRA): Field assessment form; 2009. from:http://www.who.int/hac/network/global_ health_cluster/ira_form_v2_7_eng.pdf.

5. Emergency care in natural disasters. Views of an international seminar. WHO Chron 1980;34:96-100.

6. Devi S. Helping earthquake-hit Haiti. Lancet 2010;375:267-8. CrossRef

7. Anderson MB. Do no harm: how aid can support peace - or war. London: Lynne Rienner Publishers; 1999.

8. Habibzadeh F, Yadollahie M, Kucheki M. International aid in disaster zones: help or headache? Lancet 2008;372:374. CrossRef

9. Van Hoving DJ, Wallis LA, Docrat F, De Vries S. Haiti disaster tourism- 
-a medical shame. Prehosp Disaster Med 2010;25:201-2. CrossRef

10. Humanitarian Accountability Partnership International. The Humanitarian Accountability Report 2006. Geneva: HAPInternational;2006. Available from: http://www.hapinternational.org.

11. Bajkiewicz C. Evaluating short-term missions: how can we improve? J Christ Nurs 2009;26:110-4, CrossRef

12. Ver Beek K. The impact of short-term missions: a case study of home construction after hurricane Mitch. www.calvin.edu/sociology; 2005.
13. Graves M. The benefits of short-term volunteer health work in developing nations as reported by health professionals: a content analysis (master's thesis). www.calvin.edu/academic/sociology, 1997.

14. Jobe K. Disaster relief in post-earthquake Haiti: unintended consequences of humanitarian volunteerism. Travel Med Infect Dis 2011;9:1-5. CrossRef

15. Benjamin E, Bassily-Marcus AM, Babu E, Silver L, Martin ML. Principles and practice of disaster relief: lessons from Haiti. Mt Sinai J Med 2011;78:306-18. CrossRef

\section{KISA RAPOR - ÖZET}

\section{Süper Haiyan tayfunu felaketinde tıbbi yardım:}

Yerel sağlik ekipleriyle işbirliği büyük bir sinerji içinde gerçekleşmiştir

Dr. Hoon Kim, ${ }^{1}$ Dr. Moo Eob Ahn, ${ }^{2}$ Dr. Kang Hyun Lee, ${ }^{3}$ Dr. Yeong Cheol Kim, ${ }^{4}$ Dr. Eun Seok Hong ${ }^{5}$

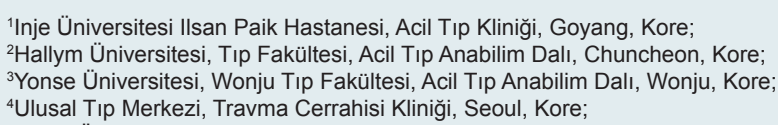

AMAÇ: Sekiz Kasım 2013 tarihinde Haiyan tayfunu Filipinler'in merkezinde toprak kaymalarına neden olmuş ve bölgeyi yerle bir etmiştir. Bu felaketten hemen sonra birçok yabancı sağık ekibi bölgeye hareket etmiştir. Kore ekibi de onlardan biriydi.

GEREÇ VE YÖNTEM: Bu çalışma ilk yardım döneminde yerel sağlık ekibiyle işbirliği çabalarına odaklanarak ilk etapta ekibin deneyimlerini anlatmaktadır.

BULGULAR: Kore ekibi birincil bakımı sağlayabilmiş, Filipin ekibi hasta yükünü kapsamak için yetersiz ikincil bakım hizmeti sağlamıştır. Kore ekibi hastanenin çalışması için elektrik ve değişik malzemeler sağlamakla kalmamış, acil ve poliklinikler için tıbbi personel katkısında bulunmuştur. Ortak işbirlikçi çabalarla birbirlerinin açığını doldurmuş, sonuçta büyuk bir sinerji oluşmuştur.

TARTIŞMA: Yabancı sağıık ekibinin afetlerde tıbbi yardım misyonu bir koordinasyon mekanizması içinde işbirliği için çalışmalıdır. Yerel kaynaklarla işbirliği her iki taraf için büyük bir fırsat olabilir ve herhangi bir afet durumunda gözden kaçırımamalıdır.

Anahtar sözcükler: Afet; işbirliği; tayfun.

Ulus Travma Acil Cerr Derg 2015;2I (2): 143-I48 doi: 10.5505/tjtes.2015.54770 